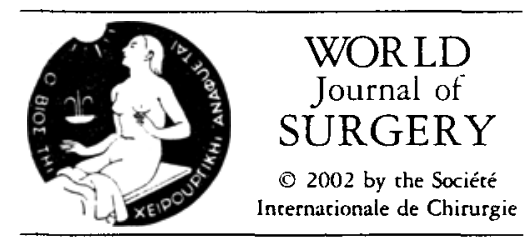

\title{
Long-term Survival of Patients with Stage IV Hypopharyngeal Cancer: Impact of Fundus Rotation Gastroplasty
} \author{
Peter Zbären, M.D., ${ }^{3}$ Markus W. Büchler, M.D. ${ }^{1}$ \\ ${ }^{1}$ Department of Visceral and Transplant Surgery, University of Bern, Inselspital, 3010 Bern, Switzerland \\ ${ }^{2}$ Department of Radiation Oncology, University of Bern, Inselspital, 3010 Bern, Switzerland \\ ${ }^{3}$ Department of Head and Neck Surgery, University of Bern, Inselspital, 3010 Bern, Switzerland
}

Martin K. Schilling, M.D., ${ }^{1}$ Martin Eichenberger, M.D., ${ }^{1}$ Christoph A. Maurer, M.D., ${ }^{1}$ Richard Greiner, M.D., ${ }^{2}$

Published Online: February 25, 2002

\begin{abstract}
Stage IV circular hypopharyngeal cancer is a disease with poor long-term survival, and the only means of cure-surgery-is associated with high morbidity. All patients admitted with circular hypopharyngeal cancer and extension to the esophagus were enrolled in a multidisciplinary treatment protocol, including circular laryngopharyngoesophagectomy with tracheostomy, neck dissection, and pull-up of a fundus rotation gastric tube that was anastomosed to the oropharynx. Five weeks postoperatively high-dose radiotherapy $(60 \mathrm{~Gy}$ ) was given to the cervical region. Altogether, 18 qualifying patients were explored cervically, were found to have resectable lesions (i.e., without carotid artery infiltration), and were included in the protocol. After laryngopharyngoesophagectomy, an elongated gastric tube was pulled up to the oropharynx. The average distance bridged with the tube was $32 \pm 4 \mathrm{~cm}$. No anastomotic leaks were found on postoperative Gastrografin swallow, and oral feeding was started between days 5 and 8 . Patients were discharged with normal oral feeding on day 21 ( \pm 17 days). Diarrhea, postprandial fullness, and reflux resolved within 6 months postoperatively. Five patients died during the follow-up period of 42 months (range 3-63 months): three due to cardiac events 18 and 38 months postoperatively and two within 12 months with residual disease and tumor recurrence, respectively. The estimated 5-year survival was $60 \%$. We concluded that an aggressive multidisciplinary approach including circular laryngopharyngoesophagectomy, neck dissection, and high-dose radiotherapy ascertains good long-term survival and good functional results in patients with advanced hypopharyngeal cancer when the intestinal continuity is reconstructed with a fundus rotation gastroplasty.
\end{abstract}

The dismal outcome of advanced-stage hypopharyngeal cancer is determined by tumor biologic factors and late patient presentation $[1,2]$ as well as by inconsistent treatment strategies [3-6]. Although oncologic aspects require a circular laryngopharyngectomy [7] and postoperative irradiation $[4,8]$, the short life expectancy of these patients mandates the acknowledgment of palliative aspects such as their swallowing capability and overall quality of life. The difficult reconstructive procedure after circular laryngopharyngoesophagectomy has been approached with a total gastric pull-up by Ong and Lee [9]. Their procedure, however, was not favored by many Western surgeons owing to the high anastomotic

Comespondence to: M.K. Schilling, M.D., e-mail: martin.schilling@unikliniksaarland.de leakage rate when anastomoses are performed at the cervical [10] let alone the oropharyngeal [11] level, so free jejunal grafts have been introduced. We recently addressed the anatomic and functional problems of esophageal reconstruction by developing a gastric tube from the whole gastric fundus $[12,13]$. By maintaining the vascular arcade along the greater and lesser curvatures, the fundus rotation gastroplasty was not only longer than conventional gastric tubes but also better perfused [14]. This technique has enabled us to anastomose the tubulated stomach to the hypopharynx safely after high esophageal resections.

We here present the functional and oncologic results in patients with stage IV hypopharyngeal cancer undergoing a treatment protocol that included a circular laryngopharyngoesophagectomy, pull-up of an elongated gastric tube (fundus rotation gastroplasty), and early postoperative radiation therapy.

\section{Patients and Methods}

Between February 1994 and February 2000 a series of 18 consecutive patients with hypopharyngeal cancer and extension to the esophagus were enrolled in a multidisciplinary treatment protocol that included circular laryngopharyngectomy, homolateral radical neck dissection $(n=18)$, contralateral modified radical or selective neck dissection $(n=14)$, and transhiatal esophagectomy. The alimentary tract continuity was restored by a transmediastinal pull-up of an elongated gastric tube: the fundus rotation gastroplasty.

\section{Fundus Rotation Gastroplasty: Technique}

After mobilizing the stomach and dissecting the left gastric artery at the celiac trunk, a horizontal cut approximately $3 \mathrm{~cm}$ below the esophagogastric junction is performed with a linear stapler. The cut is extended along the greater curvature with the stapler, leaving a 3- to 4-cm wide isoperistaltic gastric tube (Fig. 1). This tube is anastomosed (using a double-layer technique) with the 


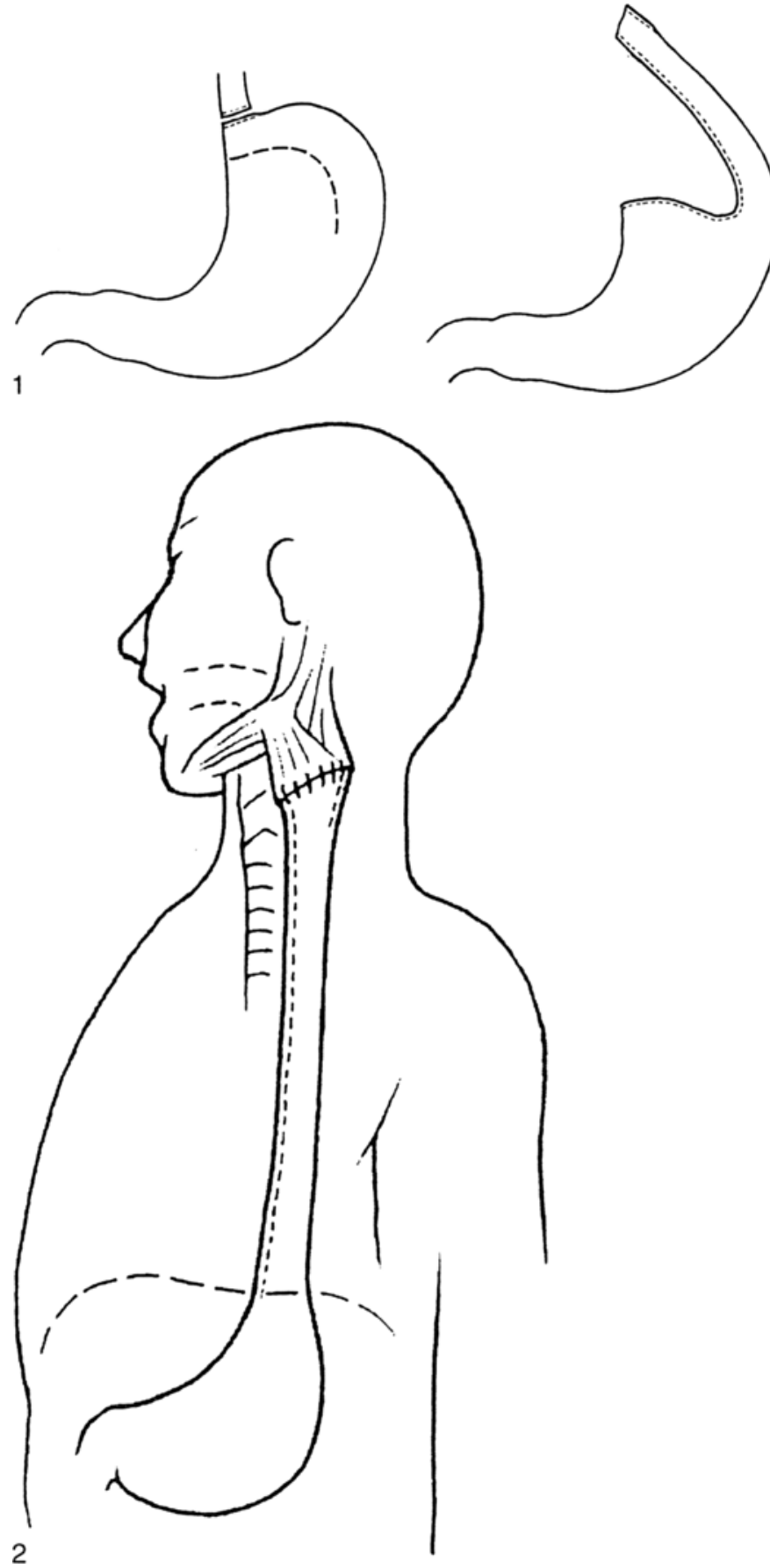

2

Fig. 1. After mobilizing the stomach and dissecting the left gastric artery at the celiac trunk a horizontal cut is made approximately $3 \mathrm{~cm}$ below the esophagogastric junction with a linear stapler. The cut is then extended along the greater curvature with the stapler, leaving a $3-$ to $4-\mathrm{cm}$ wide isoperistaltic gastric tube.

Fig. 2. Isoperistaltic tube is anastomosed with the oropharynx using a double-latyer technique.

oropharynx (Fig. 2). A tracheostomy is performed, and the patient is extubated within 12 hours of operation.

A Gastrografin swallow was performed between postoperative days 5 and 8 , and enteral feeding was started immediately there- after. Starting not earlier than postoperative week 5 , adjuvant radiotherapy of 60 to 65 Gy was applied to the clinical target volume including the anastomosis and the regional lymph nodes.

All demographic, disease-related, and intra- and postoperative data were collected prospectively and entered in a database. Patients were follcwed for postoperative outcome, including functional results. Symptoms such as dysphagia, diarrhea, acid reflux, and postprandial fullness were inquired about on a questionnaire and quantitated with a Vesnick scale. Because of the extent of the procedure, including laryngectomy, overall satisfaction with the procedure was measured with a visual analog scale. Overall survival was estimated with the Kaplan-Meier method.

\section{Results}

Over a 72-month period 18 consecutive patients (14 male, 4 female; mean age 59 years) with advanced-stage hypopharyngeal cancer (UICC stage IV; 12 with larynx invasion, 9 with invasion of the esophagus) underwent circular laryngopharyngectomy with transhiatal esophagectomy and pull-up of a fundus rotation gastroplasty. One patient with a normal preoperative cardiovascular workup died postoperatively from a transmural myocardial infarction. The other patients $(n=17)$ were extubated within 12 hours and transferred to the regular ward between the second and third postoperative day. Of these 17 patients, 1 died on the regular ward, also due to a myocardial infarction.

A postoperative Gastrografin swallow was performed between postoperative days 5 and 8 to exclude anastomotic leakage. The nasogastric tube was removed thereafter, and oral feeding was started in all patients.

During the second postoperative week one patient developed a tracheogastric fistula at the site of the tracheal tube cuff. The anastomosis itself was normal on endoscopy. The patient was reoperated, and a pedicled trapezius muscle flap was interposed between the trachea and the gastric tube. The patient recovered uneventfully from that second operation. Patients were discharged from the hospital on day 21 ( \pm 17 days), all with normal oral feeding. Moderate dysphagia persisted for 6 months but resolved within 1 year. Patients experienced mild to moderate diarrhea, postprandial fullness, and reflux for the first 6 months postoperatively (Fig. 3). One year postoperatively the overall satisfaction with the procedure in 12 patients alive and without disease was $78 \% \pm 30 \%(100 \%$ is total satisfaction; $0 \%$ is total dissatisfaction). Two recurrence-free patients died from cardiac events 18 and 38 months postoperatively. Two patients died within 12 months: one with residual disease after surgery and one with regional recurrence of the disease (Table 1). The 3- and 5-year survival probabilities (cardiac events included) were $72 \%$ and $60 \%$, respectively (Fig. 4).

\section{Discussion}

Despite surgical and combined multimodal efforts. advanced squamous cell carcinoma of the hypopharynx remains a highly lethal disease [15-18]. Systemically disseminated disease is rarely seen early in patients with hypopharyngeal cancer, so locoregional control is the major determinant for overall survival [11]. The extent of resection (i.e., the need for esophagectomy) and the mode of surgical reconstruction have been the main focuses of 


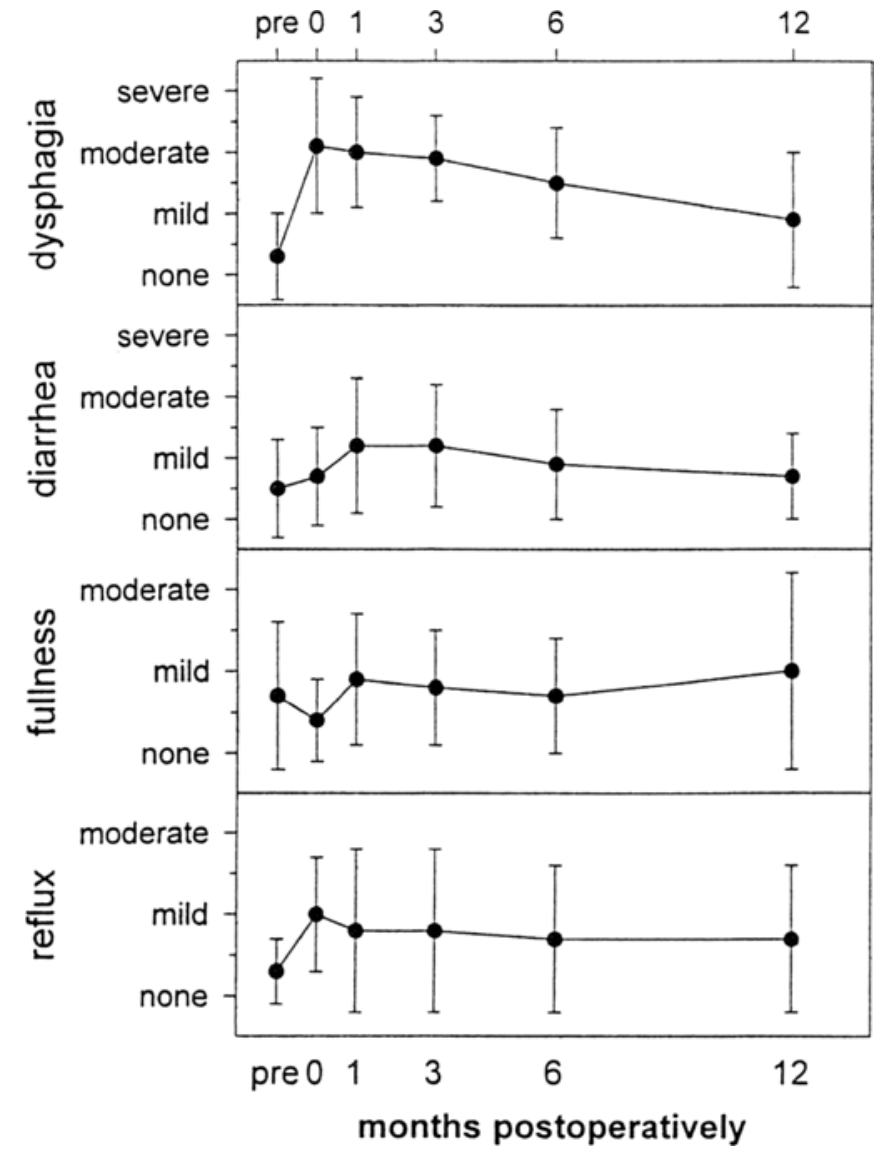

Fig. 3. Postoperative swallowing and digestive symptoms in 11 patients undergoing circular laryngopharyngectomy and esophagectomy for $\mathrm{T} 4$ hypopharyngeal cancer with extension to the esophagus. pre: time prior to start of the disease.

discussion. Some advocate total esophagectomy $[5,7]$ to resect frequent secondary lesions in the esophagus, whereas others avoid esophagectomy at the cost of radicality because of the associated high morbidity in the form of anastomotic failure seen with pharyngointestinal anastomoses [11]. Controversy centers not only on the extent of the resection but also on the organ used to reconstruct the alimentary tract.

In Asians the gastric length [19] might facilitate a tension-free pull-up of a tubulated stomach [9], and in Western populations high cervical esophagogastric anastomoses and pharyngogastric anastomoses are frequently performed under tension and are thus prone to anastomotic failure [11]. Therefore free jejunal autografts have been advocated by several European and American centers [20-22]. The critical radiosensitivity of the small bowel, however, limits the application of adjuvant radiotherapy and might thus limit control of local disease recurrence. Furthermore, radiotherapy causes considerable jejunal graft fibrosis and reduces graft function to only $60 \%$ [23]. Bolus transport after interposition of a denervated jejunal graft is of further concern, and Barrett and coworkers found that one of four patients undergoing free jejunal autotransplantation after circular pharyngectomy required a permanent nasogastric feeding tube. The remaining patients needed nasogastric tubes for several months [24].
Table 1. Operative characteristics and postoperative outcome in 18 patients undergoing circular laryngopharyngectomy and esophagectomy for stage IV circular hypopharyngeal cancer.

\begin{tabular}{lc}
\hline Parameter & Result \\
\hline Intraoperative blood loss (ml) & $1700 \pm 150$ \\
Red blood cells transfused (units) & $3 \pm 2$ \\
Operating room time (hours) & $7.1 \pm 1.2$ \\
Morbidity (no.) & \\
$\quad$ ARDS & 1 \\
Myocardial infarction & 2 \\
Anastomotic leak & 0 \\
$\quad$ Tracheogastric fistula & 1 \\
Mortality (no.) & 2 \\
In-hospital stay (days) & $21 \pm 17$ \\
Follow-up (months) & $42(3-63)$ \\
Survival (months) & $33(1-63)$ \\
Outcome (no.) & \\
Alive and well & $12 / 18$ \\
Died of disease & $2 / 18$ \\
Died of other causes & $2 / 18$ \\
Hospital mortality & $2 / 18$ \\
\hline
\end{tabular}

Data are given as the mean \pm SD or mean and range. ARDS: adult respiratory distress syndrome.

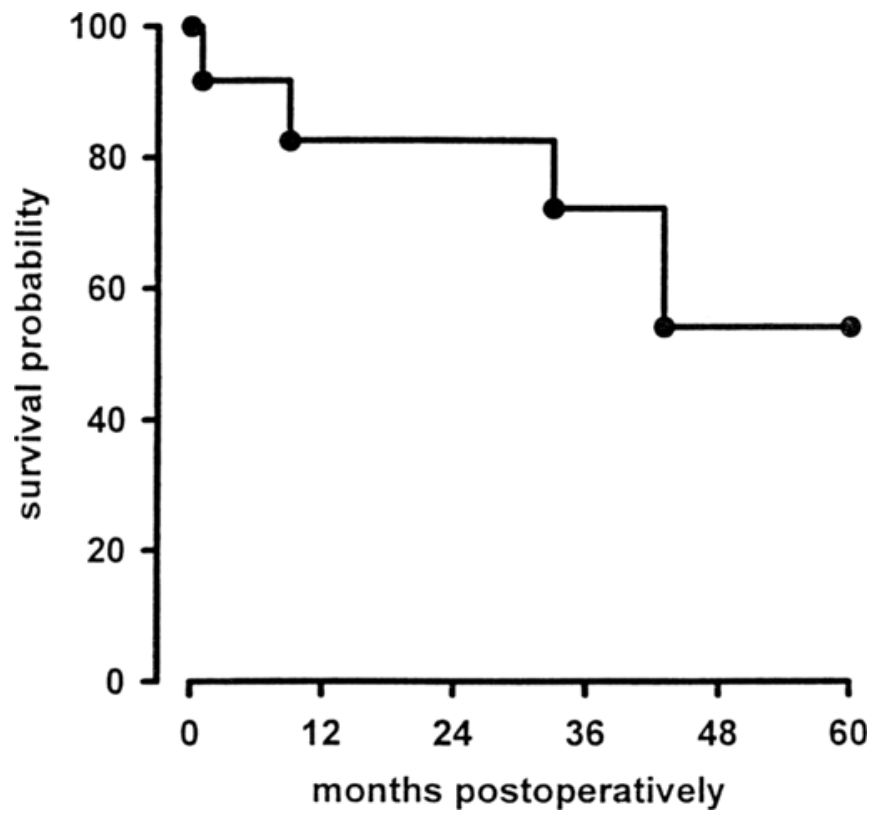

Fig. 4. Actuarial survival (Kaplan-Meier) after circular laryngopharyngectomy and esophagectomy for stage IV circular hypopharyngeal cancer.

The treatment concept presented here is based on a reconstruction that uses the whole gastric fundus [12-14] to form an elongated isoperistaltic gastric tube. In addition to the radical local resection, this tube allowed resection of the esophagus and a tension-free reconstruction between the tube and the oropharynx in all 18 patients. Furthermore, radiotherapy up to 65 Gy could be applied to the target volume postoperatively without jeopardizing the pharyngogastric anastomosis, and no alterations in tubular function were apparent clinically. No anastomotic leaks were found clinically or radiologically, and all patients were started on enteral feeding 5 to 8 days postoperatively. 
In addition to the radical local approach, the high-dose radiotherapy ascertained a low locoregional recurrence rate (in only 2 of the 18 ) and a 5 -year total survival rate of $60 \%$. (Most other reports give 4- to 5-year survival rates of 0 to $20 \%$ in patients with comparable disease stages.) In a series of 34 patients, Sasaki et al. [25] reported a 3-year survival of $36 \%$ albeit with a surgical approach only; and Frank et al. [11], with a combined surgicalradiotherapeutic approach, reported an overall 5-year survival of $48 \%$. However, only half of their patients had advanced tumors (stage IV), and their anastomotic failure rate was $24 \%$.

Even though the number of patients in this series is limited, the exceptionally high survival rates and the high satisfaction with the procedure justifies recommending this aggressive surgical approach for stage IV circular hypopharyngeal cancer. Such an approach includes circular laryngopharyngoesophagectomy, neck dissection, reconstruction with a fundus rotation gastroplasty, and high-dose postoperative radiotherapy.

Résumé. En cas de cancer circonférentiel de l'hypopharynx stade IV, la survie est médiocre. Le seul moyen de cure possible, la chirurgie, est grevé d'une morbidité élevée. Tous les patients admis pour cancer circonférentiel de l'hypopharynx avec envahissement de l'oesophage ont été enregistrés dans un protocole de traitement multidisciplinaire, comprenant une laryngopharyngo-oesphagectomie avec trachéostomie, une lymphadénectomie cervicale et une gastroplastie tubulisée au dépens du fundus gastrique anastomosé à l'oropharynx. Cinq semaines après, une radiothérapie à haute dose (de $60 \mathrm{~Gy}$ ) a été délivrée à la région cervicale. Dix-huit patients remplissant ces conditions ont eu une exploration cervicale et ont été considérés comme potentiellement résecables (c'est-à-dire sans infiltration de l'artère carotide). Après laryngo-pharyngo-esophagectomie, un tube gastrique a été monté à l'oropharynx. La distance moyenne du tube a été de $32 \pm 4 \mathrm{~cm}$. Aucune fistule anastomotique n'a été retrouvée sur l'examen postopératoire à la gastrografine et on a pu commencer l'alimentation orale entre les jours postopératoires 5 et 8 . Les patients ont pu quitter l'hôpital s'alimentant normalement au jour 21 ( \pm 17 jours). En ce qui concerne la morbidité postopératoire, diarrhée, sensation de plénitude postprandiale et reflux se sont résolus en moins de six mois après l'opération. Cinq patients sont décédés pendant la période de suivi de $\$ 2$ mois (extrèmes 3-63 mois), trois, d'évènements cardiaques, 18 et 38 mois postopératoire et deux patients, respectivement, de maladie résiduelle et de récidive tumorale, en moins de 12 mois. La survie à 5 ans a été de $60 \%$. Chez les patients atteints de cancer de l'hypopharynx avancé, une approche multidisciplinaire agressive comprenant une laryngo-pharyngoesophagectomie circulaire, la lymphadénectomie cervicale et la radiothérapie à haute dose, assurent une bonne survie à long terme et de bons résultats fonctionnels lorsque la continuité intestinale est rétablie par une gastroplastie de rotation fundique.

Resumen. El cáncer hipofaríngeo de los pliegues circulares, estadio IV, es una afección con escasa supervivencia a largo plazo y cuya curación, exclusivamente quirúrgica cursa con elevada morbilidad. Todos los pacientes con dicho tipo de cáncer que además, se propaga al esófago, fueron incluidos en un protocolo de tratamiento multidisciplinario consistente en una laringo-faringo-esofagectomía circular con traqueostomía y vaciamiento ganglionar del cuello, anastomosándose un tubo del fundus gástrico rotado a la orofaringe. Transcurridas 5 semanas de la intervención se aplicó sobre la región cervical, radioterapia, a dosis altas: 60 Gy. En 18 pacientes en los que la cervicotomía exploradora demostró la resecabilidad (i.e., sin intiltración de la arteria carótida) se incluyeron en el mencionado protocolo. Tras la laringo-faringoesofagectomia un elongado tubo gástrico se ascendió para anastomosarlo a la orofaringe. La deglución de gastrografin no reveló ninguna dehiscencia anastomótica y la alimentación oral se instauró entre los días 5 y 8 del postoperatorio. Los pacientes fueron dados de alta con alimentación oral normal a los 21 días $( \pm 17$ días). Diarreas, pesadez postprandial y reflujo desaparecieron a lo largo de los primeros seis meses del postoperatorio. 5 pacientes fallecieron durante el seguimiento, superior a 42 meses (rango 3-63 meses); tres, a los 18 y 38 meses de la intervención por problemas cardiacos; los otros dos murieron antes de 12 meses por enfermedad residual o recidivante. La supervivencia estimada a los 5 años fue del $60 \%$. En pacientes con cáncer hipofaríngeo avanzado un tratamiento agresivo multidisciplinario que incluye no sólo la resección laringo-faringo-esofágica sino también el vaciamiento ganglionar del cuello y radioterapia postoperatoria a dosis altas permite un elevado porcentaje de supervivencia a largo plazo con buenos resultados funcionales, cuando la continuidad del tubo digestivo se restablece con una gastroplastia de rotación fúndica.

\section{References}

1. Zbaren P, Becker M, Lang H. Pretherapeutic staging of hypopharyngeal carcinoma: clinical findings, computed tomography, and magnetic resonance imaging compared with histopathologic evaluation. Arch. Otolaryngol. Head Neck Surg. 1997;123:908-913

2. Zbaren P, Egger C. Growth patterns of piriform sinus carcinomas. Laryngoscope 1997; 107:511-518

3. Kumar PP, Good RR, Epstein BE, et al. Outcome of locally advanced stage III and IV head and neck cancer treated by surgery and postoperative external beam radiotherapy. Laryngoscope 1987;97:615-620

4. Wennerberg J. Pre versus post-operative radiotherapy of resectable squamous cell carcinoma of the head and neck. Acta Otolaryngol. $1995 ; 115: 465-474$

5. Laterza E, Mosciaro O, Urso US, et al. Primary carcinoma of the hypopharynx and cervical esophagus: evolution of surgical therapy. Hepatogastroenterology 1994;41:278-282

6. Kramer S, Gelber RD, Snow JB, et al. Combined radiation therapy and surgery in the management of advanced head and neck cancer: final report of study 73-03 of the Radiation Therapy Oncology Group. Head Neck Surg. 1987;10:19-30

7. Gluckman JL, Weissler MC, McCafferty G, et al. Partial vs total esophagectomy for advanced carcinoma of the hypopharynx. Arch. Otolaryngol. Head Neck Surg. 1987;113:69-72

8. Frank JL, Garb JL, Kay S, et al. Postoperative radiotherapy improves survival in squamous cell carcinoma of the hypopharynx. Am. J. Surg. 1994: $168: 476-480$

9. Ong GB, Lee TC. Pharyngo-gastric anastomosis after esophago-pharyngectomy for carcinoma of the hypopharynx and the cervical esophagus. Br. J. Surg. 1960;48:193-200

10. Bumm R, Hölscher AH. Fuessner $H$, et al. Endodissection of the thoracic esophagus: technique and clinical results in transhiatal esophagectomy. Ann. Surg. 1993;218:97-104

11. Frank JL, Garb JL, Saul K. et al. Postoperative radiotherapy improves survival in squamous cell carcinoma of the hypopharynx. Am. J. Surg. 1994; 168:476-480

12. Büchler MW, Seiler C, Baer HU, et al. A technique for gastroplasty as a substitute for the esophagus: fundus rotation gastroplasty. J. Am. Coll. Surg. 1996;182:241-245

13. Schilling MK, Redaelli C. Zbären P, et al. First clinical experience with fundus rotation gastroplasty as a substitute for the oesophagus. Br. J. Surg. 1997;84:126-128

14. Schilling MK, Mettler D. Reduelli C, et al. Differences between conventional, reversed and fundus rotation gastric tubes as esophageal replacement. World J. Surg. 1997;21:992-997

15. Kajanti M, Mantyla M. Carcinoma of the hypopharynx: a retrospective analysis of the treatment results over a 25 -year period. Acta Oncol. 1990;29:903-907

16. Olsen KD, Lewis JE, Suman VJ. Spindle cell carcinoma of the larynx and hypopharynx. Otolaryngol. Head Neck Surg. 1997:116:47-52

17. Kraus DH, Zelefsky MJ, Brock HA, et al. Combined surgery and radiation therapy for squamous cell carcinoma of the hypopharynx. Otolaryngol. Head Neck Surg. 1997;116:637-641

18. Kojima K. Suzuki K. Ito Y. et al. Tracking of hypopharyngeal carcinoma over 10 years. Acta Otolaryngol. Suppl. 1996;525:1+6-150

19. Goldsmith HS, Akiyama H. A comparative study of Japanese and American gastric dimensions. Ann. Surg. 1979;190:690-693

20. Julieron M, Germain MA. Sihwaab G, et al. Reconstruction with free jejunal autograft after circumferential pharyngolaryngectomy: eightythree cases. Ann. Otol. Rhinol. Laryngol. 1998:107:581-587 
21. Chevalier D, Triboulet JP. Patenotre P, et al. Free jejunal graft reconstruction after total pharyngolaryngeal resection for hypopharyngeal cancer. Clin. Otolarngol. 1997:22:41-43

22. Wilson JA, Maran AG. Pryde A, et al. The function of free jejunal autografts in the pharyngo-oesophageal segment. J.R. Coll. Surg. Edinb. 1995;40:363-366

23. Rath $T$, Grasl MC. Burian M. et al. Late functional outcome after reconstruction of the upper aerodigestive tract with free transplanted microvascular anastomosed jejunum. Handchir. Mikrochir. Plast. Chir. 1997;29:269-277

24. Barrett WL. Gluckman JL, Aron BS. Safety of radiating jejunal interposition grafts in head and neck cancer. Am. I. Clin. Oncol. 1997;20:609-612; DOI: 10.1097/00000421-199712000-00016

25. Sasaki CT, Salzer SJ, Cahow E, et al. Laryngopharyngoesophagectomy for advanced hypopharyngeal and esophageal squamous cell carcinoma: the Yale experience. Laryngoscope 1995:105:160-163 